\title{
Mapping the Evolution Trends in Interactive Storytelling: A Bibliometric Analysis
}

\author{
https://doi.org/10.3991/ijim.v15i20.23713 \\ Norbayah Mohd Suki ${ }^{1(凶)}$, Norazah Mohd Suki², Rosliza Ahmad ${ }^{3}$ \\ ${ }^{1}$ Universiti Utara Malaysia, Sintok, Malaysia \\ ${ }^{2}$ Universiti Utara Malaysia, Kuala Lumpur, Malaysia \\ ${ }^{3}$ Universiti Selangor, Selangor, Malaysia \\ bayasuki@yahoo.com
}

\begin{abstract}
The explosions of new media led the studies of interactive storytelling in the area of creative industry. Future research directions are call upon for the growth benefits of this research field. Thus, this study aims to assess the evolution of publication trends in interactive storytelling between the year of 1996 to 2020 through a bibliometric analysis. A sample of 795 studies from the SCOPUS database were analysed via the VOSviewer and Harzing's Perish or Publish software tools to distinguish research activity on interactive storytelling. The identification of the dominant articles and authors are traced based on the event of the citations, publications, its location and network. The highest number of publications is observed in 2011, with a total of 71 documents (8.93\%). The subject of Computer Science is majorly depicted on the studies of Interactive Storytelling (53.5\%), followed with Mathematics (24.53\%). Meanwhile, the subjects of Engineering $(7.30 \%)$, Social Sciences $(6.47 \%)$, and Arts and Humanities $(3.99 \%)$ contributing to the total publications of Interactive storytelling. Furthermore, computer science and mathematics subject are the most represented for the studies of Interactive Storytelling to explain the complexity and technicality aspects of the scientific narratives with the compelling features of the interactivity.
\end{abstract}

Keywords-interactive storytelling, creative industry, bibliometric analysis, scopus, VOSviewer

\section{Introduction}

Story is essential in our life. The convergences of technology and interactivity into narratives enrich the storytelling deliverances to the viewer [1]. The prospects of interactive storytelling as the potential medium for promoting rich content in the creative industry should be taken into considerations by the industry player and the academia [2]-[3]. Minimal research has been investigated on evolution trends of interactive storytelling globally. Thus, highlights on theinteractive storytelling analysis are carried out with the recommendation on the directions of the future research. Due to the importance of interactive storytelling to the creative industry growth, it is vital to determine its research trends and progression. Accordingly, this study aims to assess the evolution of 
publication trends in interactive storytelling between the year of 1996 to 2020 through a bibliometric analysis which is viewed through Scopus database.

\section{$2 \quad$ Literature review}

Interactive storytelling is also known as Interactive narrative. Studies made by previous researchers established that interactive storytelling happens digitally in the virtual world in the form of non-linear structure with certain control assigned to the user and this non-linearity affects the users through dramatic storyline, interactivity and character performances [4]-[5].

Interestingly, broad application of interactive storytelling can be seen in entertainment, infotainment and edutainment sectors globally $[2,3,6]$. Besides this, several medium of interactivity are identified by recent researchers for the interactive storytelling namely the Virtual Reality (VR) storytelling that utilizes virtual environments (VE), interactive 3D applications and Interactive web document arises that promotes user engagement to the topics through innovative storytelling approaches [6]-[8]. In searching about how interactive storytelling can be compelling to the user, the answer lies within numerous factors namely the augmentation of the real-world and physically-based interaction to the narrative immersive experience influenced by the user actions thus lead to the active audience participation [9]. In addition, it is observed that the employment of user-friendly interaction using depth motion sensing and hand gestures control technology in storytelling, plus the interactive 3D applications enhances user experience, their exposure to geospatial data complexity, thus offering many choices in maneuvering the same story $[8,10]$. This necessitate the need to venture the possibilities of interaction design, human-computer interaction, and user experience as the new disciplines that is quint essential for the representation and design of data interaction dynamics to the interactive storytelling field of study from the contexts of education [11]. In light of this, a bibliometric analysis is conducted to explore the evolution trends in interactive storytelling.

\section{Methods}

Data of the current study were collected from Scopus database as at 13th January 2020. A sample of 795 studies from the SCOPUS database were analysed via the VOSviewer and Harzing's Perish or Publish software tools. Scopus database is acknowledged as the "largest single abstract and indexing database ever built" and the "largest searchable citation and abstract source of searching literature". The query: TITLE ("Interactive storytelling") was conducted with 795 search documents sought from the database. Research on interactive storytelling is conducted to find the structure of research based on the bibliometric analysis [12]. The structure and central themes of a research area is depicted using the combination of social network analysis [13]. The identification of current trends and future research avenues is made enable with a bibliometric analysis [14]. Figure 1 illustrates the research structure employed in this study. 

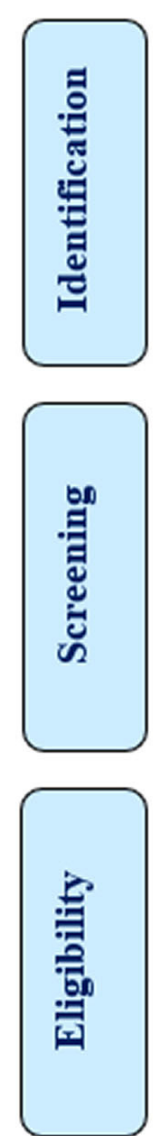

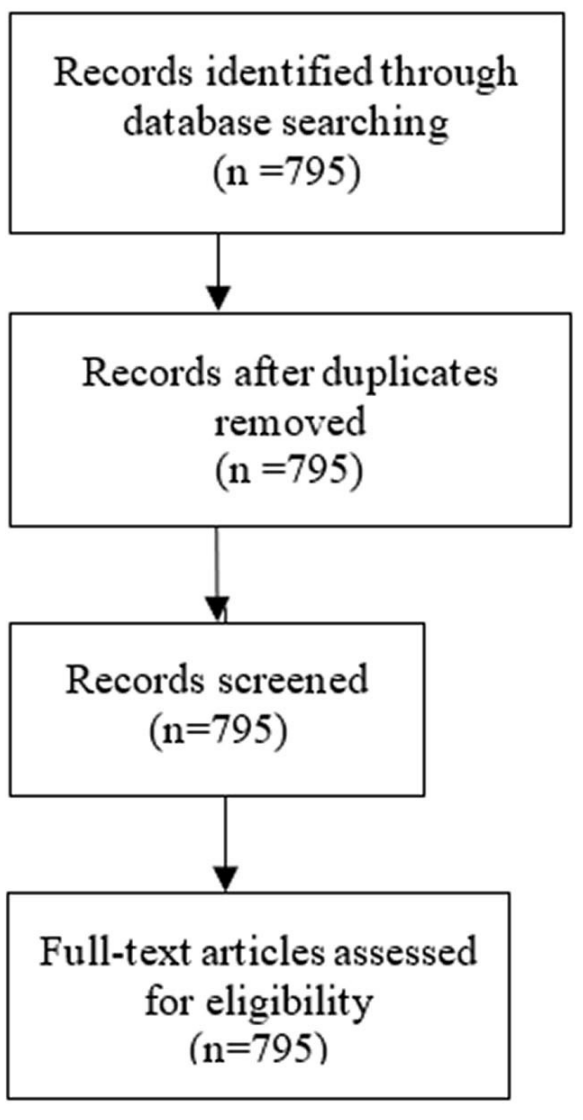

Fig. 1. PRISMA flow diagram

\section{Results}

\subsection{Document and source types}

Table 1 itemise that major documents types were derived from conference paper (74.5\%), followed with article (16\%) and conference review (6.3\%).

Table 1. Document type

\begin{tabular}{|l|c|c|l|c|c|}
\hline \multicolumn{1}{|c|}{ Document Type } & Freq. & $\mathbf{\%}$ & \multicolumn{1}{c|}{ Document Type } & Freq. & \% \\
\hline Conference Paper & 592 & 74.5 & Book Chapter & 8 & 1.0 \\
\hline Article & 127 & 16.0 & Book & 6 & 0.8 \\
\hline Conference Review & 50 & 6.3 & Editorial & 1 & 0.1 \\
\hline Review & 11 & 1.4 & & & \\
\hline
\end{tabular}


Table 2 summarizes the source type published on interactive storytelling consists majorly of journals (43.5\%), followed with conference proceedings $(40.50 \%$ and book series $(14 \%)$. The balances referred to books and trade publications.

Table 2. Source type

\begin{tabular}{|l|c|c|}
\hline \multicolumn{1}{|c|}{ Source Type } & Frequency & \% (N=795) \\
\hline Journals & 346 & 43.5 \\
\hline Conference Proceedings & 322 & 40.5 \\
\hline Book Series & 111 & 14.0 \\
\hline Books & 13 & 1.6 \\
\hline Trade Publications & 3 & 0.4 \\
\hline Total & $\mathbf{7 9 5}$ & $\mathbf{1 0 0 . 0 0}$ \\
\hline
\end{tabular}

\subsection{Year of publications}

The evolution of published studies on interactive storytelling from 1996 to 2020 is illustrated in Figure 2. The highest number of publications is observed in 2011, with a total of 71 documents $(8.93 \%)$.

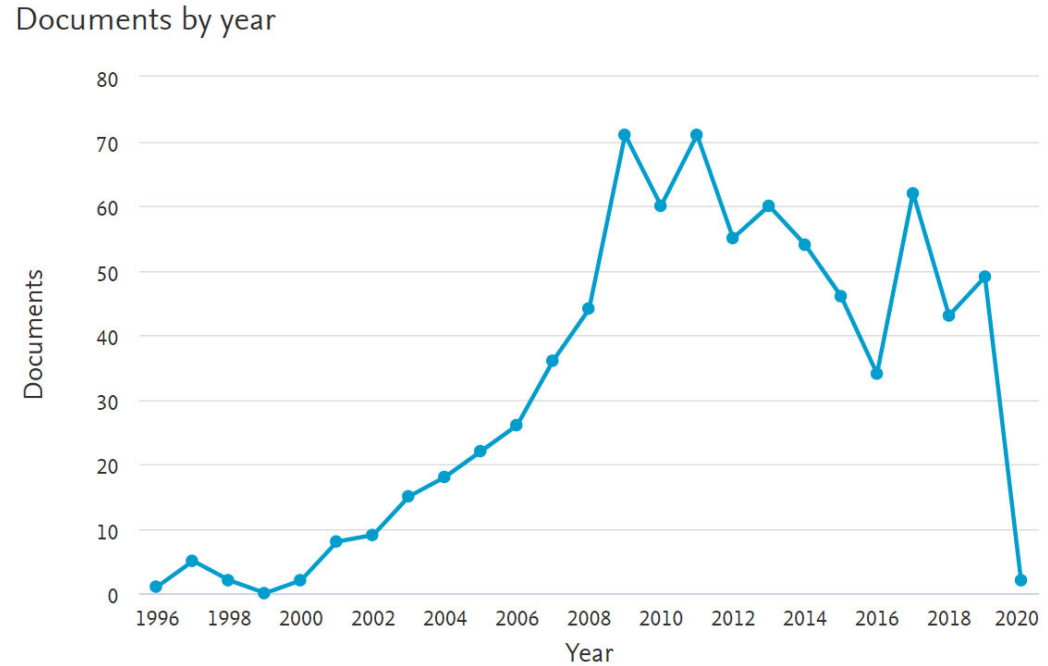

Fig. 2. Document by year

\subsection{Languages of documents}

Table 3 presented the languages used in publications with English is the main preferred language used (99.7\%). English language is the most written language used for publications globally. 
Table 3. Languages used for publications

\begin{tabular}{|l|c|c|}
\hline \multicolumn{1}{|c|}{ Language } & Frequency & $\mathbf{\%}(\mathbf{N}=\mathbf{7 9 5})$ \\
\hline English & 794 & 99.7 \\
\hline Spanish & 2 & 0.3 \\
\hline Total & $\mathbf{7 9 6}$ & $\mathbf{1 0 0 . 0 0}$ \\
\hline
\end{tabular}

\subsection{Subject area}

The subject areas are detailed in Table 4. The subject of Computer Science is majorly depicted on the studies of Interactive Storytelling (53.5\%), followed with Mathematics (24.53\%). The subjects of Engineering (7.30\%), Social Sciences (6.47\%) and Arts and Humanities $(3.99 \%)$ contributing to the total publications of Interactive storytelling. The other subject areas covered in Interactive storytelling research are enumerated in Table 4. Respectively, it is observed that computer science and mathematics subject are the most represented for the studies of Interactive Storytelling to explain the complexity and technicality aspects of the scientific narratives with the compelling features of the interactivity.

Table 4. Subject area

\begin{tabular}{|c|c|c|}
\hline Subject Area & Frequency & $\%(N=1329)$ \\
\hline Agricultural and Biological Sciences & 3 & 0.23 \\
\hline Arts and Humanities & 53 & 3.99 \\
\hline Biochemistry, Genetics and Molecular Biology & 4 & 0.30 \\
\hline Business, Management and Accounting & 2 & 0.15 \\
\hline Chemical Engineering & 3 & 0.23 \\
\hline Computer Science & 711 & 53.50 \\
\hline Decision Sciences & 9 & 0.68 \\
\hline Earth and Planetary Sciences & 2 & 0.15 \\
\hline Economics, Econometrics and Finance & 2 & 0.15 \\
\hline Energy & 1 & 0.08 \\
\hline Engineering & 97 & 7.30 \\
\hline Environmental Science & 1 & 0.08 \\
\hline Health Professions & 1 & 0.08 \\
\hline Mathematics & 326 & 24.53 \\
\hline Medicine & 7 & 0.53 \\
\hline Neuroscience & 1 & 0.08 \\
\hline Nursing & 2 & 0.15 \\
\hline Physics and Astronomy & 1 & 0.08 \\
\hline Psychology & 16 & 1.20 \\
\hline Social Sciences & 86 & 6.47 \\
\hline Undefined & 1 & 0.08 \\
\hline Total & 1329 & 100 \\
\hline
\end{tabular}




\subsection{Most active source titles}

The most active top 20 publishing venues are listed in Table 5 with the Lecture Notes in Computer Science Including Subseries Lecture Notes in Artificial Intelligence and Lecture Notes in Bioinformatics topped the list with 299 documents. This is followed by the ACM International Conference Proceeding Series with 36 documents, the Ceur Workshop Proceedings with 12 documents and the Proceedings of The International Joint Conference on Autonomous Agents and Multiagent Systems Aamas with 10 documents.

Table 5. Top 20 active publishing

\begin{tabular}{|c|c|c|}
\hline Source Title & No. of Documents & $\%$ \\
\hline $\begin{array}{l}\text { "Lecture Notes in Computer Science Including Subseries" "Lecture } \\
\text { Notes in Artificial Intelligence and Lecture Notes in Bioinformatics" }\end{array}$ & 299 & 45.65 \\
\hline "ACM International Conference Proceeding Series" & 36 & 5.50 \\
\hline "Ceur Workshop Proceedings" & 12 & 1.83 \\
\hline $\begin{array}{l}\text { "Proceedings of The International Joint Conference on Autonomous } \\
\text { Agents and Multiagent Systems Aamas" }\end{array}$ & 10 & 1.53 \\
\hline "Conference on Human Factors in Computing Systems Proceedings" & 9 & 1.37 \\
\hline "Aaai Workshop Technical Report" & 8 & 1.22 \\
\hline "Entertainment Computing" & 8 & 1.22 \\
\hline "Brazilian Symposium on Games and Digital Entertainment games" & 7 & 1.07 \\
\hline "Computers in Entertainment" & 7 & 1.07 \\
\hline "Aaai Fall Symposium Technical Report" & 6 & 0.92 \\
\hline "International Journal of Arts and Technology" & 6 & 0.92 \\
\hline "Aaai Spring Symposium Technical Report" & 5 & 0.76 \\
\hline $\begin{array}{l}\text { "International Conference on Intelligent User Interfaces Proceedings } \\
\text { IUI" }\end{array}$ & 5 & 0.76 \\
\hline $\begin{array}{l}\text { "Lecture Notes in Artificial Intelligence Subseries of Lecture Notes in } \\
\text { Computer Science" }\end{array}$ & 5 & 0.76 \\
\hline "Proceedings of The European Conference on Games Based Learning" & 5 & 0.76 \\
\hline "Communications in Computer and Information Science" & 4 & 0.61 \\
\hline "Computers and Graphics Pergamon" & 4 & 0.61 \\
\hline "IFIP Advances in Information and Communication Technology" & 4 & 0.61 \\
\hline $\begin{array}{l}\text { "Lecture Notes of The Institute for Computer Sciences Social } \\
\text { Informatics and Telecommunications Engineering" }\end{array}$ & 4 & 0.61 \\
\hline $\begin{array}{l}\text { "12th International Conference on Autonomous Agents and Multiagent } \\
\text { Systems } 2013 \text { Aamas 2013" }\end{array}$ & 3 & 0.46 \\
\hline
\end{tabular}




\subsection{Keywords analysis}

The keywords analysis is crucial to indicate the author's documents. The keyword analysis provides information about the research, primarily related topics (Wambu et al. 2017). There were $31 \%$ times of searches on keywords interactive storytelling (see Table 6).

Table 6. Top 20 keywords

\begin{tabular}{|c|c|c|}
\hline Author Keywords & Frequency & $\%$ \\
\hline Interactive Storytelling & 582 & 30.8 \\
\hline Human Computer Interaction & 202 & 10.7 \\
\hline Artificial Intelligence & 139 & 7.4 \\
\hline Virtual Reality & 138 & 7.3 \\
\hline Interactive Narrative & 104 & 5.5 \\
\hline Interactive Computer Graphics & 77 & 4.1 \\
\hline User Interfaces & 67 & 3.5 \\
\hline Interactive Stories & 62 & 3.3 \\
\hline Storytelling & 56 & 3.0 \\
\hline Computer Science & 55 & 2.9 \\
\hline Computers & 55 & 2.9 \\
\hline Education & 49 & 2.6 \\
\hline Interactive Computer Systems & 44 & 2.3 \\
\hline Computer Games & 40 & 2.1 \\
\hline Interactivity & 39 & 2.1 \\
\hline E-learning & 38 & 2.0 \\
\hline Animation & 36 & 1.9 \\
\hline Autonomous Agents & 36 & 1.9 \\
\hline Planning & 35 & 1.9 \\
\hline Digital Storytelling & 34 & 1.8 \\
\hline
\end{tabular}

Figure 3 indicated the network visualization map to understand the keywords analysis related to interactive storytelling. The key research areas and tools were extracted using VOSviewer from these keywords. Cluster differentiation were made based on the colour and size of the circles through the connection of the link of co-occurrence representation between the two keywords. Relative font size is a measure of the relative popularity of the keywords (van Eck \& Waltman, 2010). Human computer interaction, artificial intelligence, virtual reality, interactive narrative, interactive computer graphics, user interfaces and interactive stories are popular keywords pertaining to interactive storytelling. Meanwhile, Figure 4 embodied the word analysis of the total keywords specified in the author's documents. 


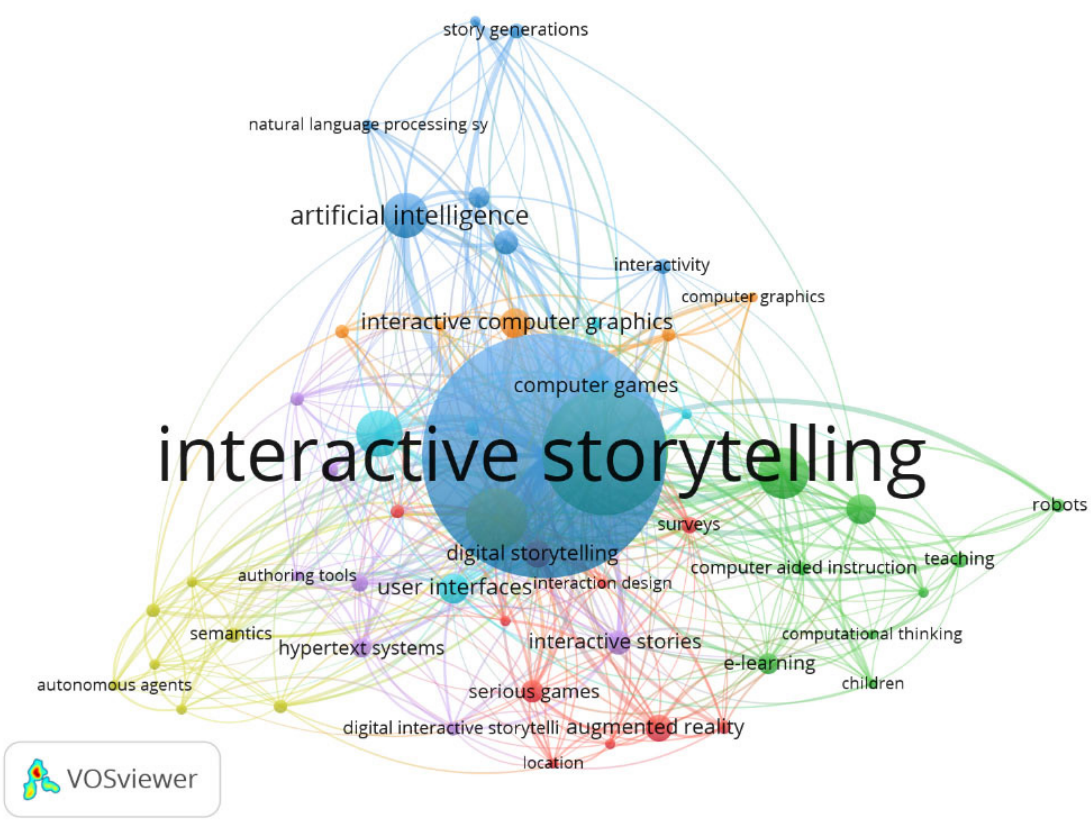

Fig. 3. Author keywords dispersed in network visualization map from 1996 to 2020

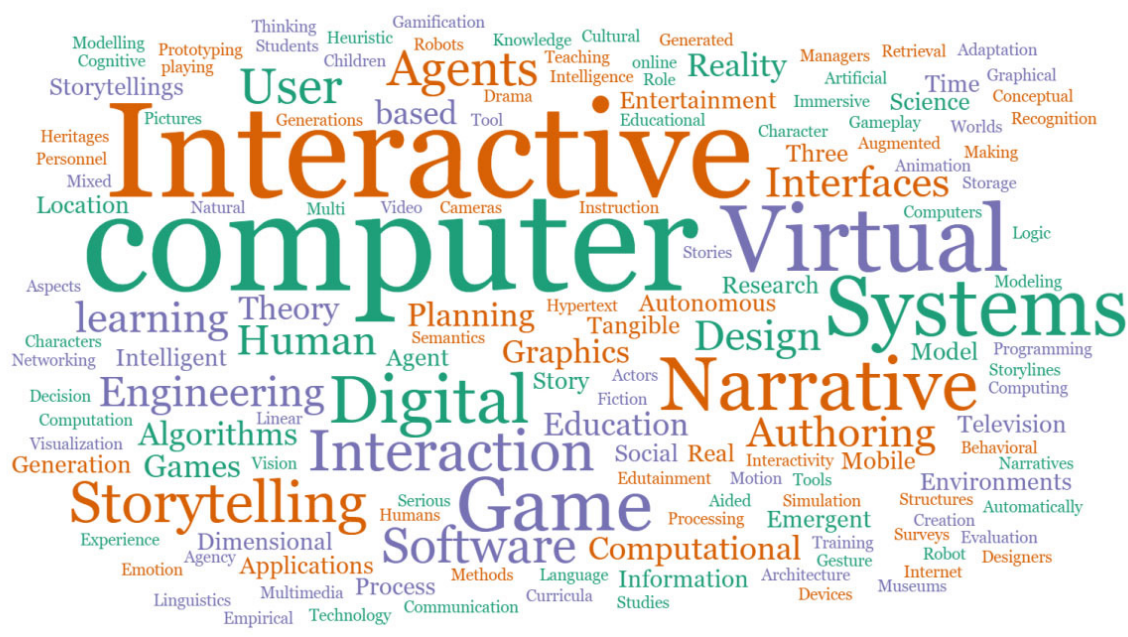

Fig. 4. Word analysis of the total keywords in author's documents

\subsection{Geographical distribution of publications}

The research productivity indicators of individual countries pertaining to interactive storytelling are made based on the geographical distribution of publications. 
Table 7 exhibits the top 20 countries that contributed to the publications which indicates the volume of publications productivity by countries. One of the top spot countries that published interactive storytelling is identified as United Kingdom is with 150 publications (15.4\%) from a total of 975 publications. United States ranked the second spot with 141 publications (14.5\%). Meanwhile the third spot is occupied by Germany with 94 publications $(9.6 \%)$.

Table 7. Top 20 countries contributed to the publications

\begin{tabular}{|l|c|c|l|c|c|}
\hline \multicolumn{1}{|c|}{ Country } & Frequency & \% (N=975) & Country & Frequency & \% (N=975) \\
\hline United Kingdom & 150 & 15.4 & Spain & 24 & 2.5 \\
\hline United States & 141 & 14.5 & Canada & 23 & 2.4 \\
\hline Germany & 94 & 9.6 & Denmark & 20 & 2.1 \\
\hline Portugal & 62 & 6.4 & Australia & 19 & 1.9 \\
\hline Brazil & 47 & 4.8 & Japan & 19 & 1.9 \\
\hline Netherlands & 44 & 4.5 & Switzerland & 18 & 1.8 \\
\hline Italy & 37 & 3.8 & Austria & 15 & 1.5 \\
\hline France & 30 & 3.1 & Greece & 14 & 1.4 \\
\hline Singapore & 27 & 2.8 & Taiwan & 13 & 1.3 \\
\hline South Korea & 25 & 2.6 & China & 12 & 1.2 \\
\hline
\end{tabular}

\subsection{Authorship}

Table 8 displays the number of authors per document. There were 159 authors that writes about 1059 documents on interactive storytelling being published by multiple authors. Co-authorship networks has visualized the relations of the authors in a social context (Melin \& Persson, 1996). In regards to the top 10 productive authors, 7 authors published more than 10 documents while the rest of the authors published less than 10 documents.

Table 8. Most productive authors

\begin{tabular}{|l|c|c|}
\hline \multicolumn{1}{|c|}{ Author's Name } & $\begin{array}{c}\text { No. of } \\
\text { Documents }\end{array}$ & $\begin{array}{c}\text { Percentage } \\
(\%)\end{array}$ \\
\hline M. Brehmer, B. Lee, B. Bach, N.H. Riche, T. Munzner & 33 & 3.12 \\
\hline W.-Y. Hwang, R. Shadiev, J.-L. Hsu, Y.-M. Huang, G.-L. Hsu, Y.-C. Lin & 29 & 2.74 \\
\hline D. Atwood-Blaine, D. Huffman & 15 & 1.42 \\
\hline F. Garzotto, M. Gelsomini, F. Clasadonte, D. Montesano, D. Occhiuto & 13 & 1.23 \\
\hline D. Harley, J.H. Chu, J. Kwan, A. Mazalek & 11 & 1.04 \\
\hline M. Nakevska, A. van der Sanden, M. Funk, J. Hu, M. Rauterberg & 11 & 1.04 \\
\hline A. Ramirez, V. Bulitko & 10 & 0.94 \\
\hline G. Dizon & 9 & 0.85 \\
\hline C. Roth, H. Koenitz & 8 & 0.76 \\
\hline T. Wallbaum, S. Ananthanarayan, S.S. Borojeni, W. Heuten, S. Boll & 7 & 0.66 \\
\hline
\end{tabular}




\subsection{Citation analysis}

The measurement of citation analysis is made upon patterns and frequency of citations that linked from one document to another. The summarisation of citations metrics gained for the period of five years (2015-2020) were enumerated from Harzing's Publish software in Table 9.

Table 9. Five years citations metrics for interactive storytelling

\begin{tabular}{|l|c|}
\hline \multicolumn{1}{|c|}{ Metrics } & Data \\
\hline Publication years & $2015-2020$ \\
\hline Citation years & $5(2015-2020)$ \\
\hline Papers & 200 \\
\hline Citations & 314 \\
\hline Citations/year & 62.8 \\
\hline Citations/paper & 1.57 \\
\hline Authors/paper & 3.26 \\
\hline h-index & 8 \\
\hline
\end{tabular}

Table 10 presents the top 10 highly cited articles classified as the most influential paper. Out of 1059 documents, the highest number of cites is 33, written by M. Brehmer, B. Lee, B. Bach, N.H. Riche, T. Munzner with the title article of "Timelines Revisited: A Design Space and Considerations for Expressive Storytelling." Article entitled "Effects of storytelling to facilitate EFL speaking using Web-based multimedia system" by W.-Y. Hwang, R. Shadiev, J.-L. Hsu, Y.-M. Huang, G.-L. Hsu, Y.-C. Lin (2016) held the second highest citations (29 times cited), followed by article "Mobile Gaming and Student Interactions in a Science Center: The Future of Gaming in Science Education" by D. Atwood-Blaine, D. Huffman (2017) was cited 15 times.

Table 10. Top 10 highly cited articles

\begin{tabular}{|c|c|c|c|c|c|}
\hline Ref. & Authors & Title & Year & Cites & $\begin{array}{c}\text { Cites } \\
\text { per Year }\end{array}$ \\
\hline 15 & $\begin{array}{l}\text { M. Brehmer, B. Lee, } \\
\text { B. Bach, N.H. Riche, } \\
\text { T. Munzner }\end{array}$ & $\begin{array}{l}\text { "Timelines Revisited: A Design Space } \\
\text { and Considerations for Expressive } \\
\text { Storytelling" }\end{array}$ & 2017 & 33 & 11 \\
\hline 16 & $\begin{array}{l}\text { W.-Y. Hwang, } \\
\text { R. Shadiev, J.-L. Hsu, } \\
\text { Y.-M. Huang, } \\
\text { G.-L. Hsu, Y.-C. Lin }\end{array}$ & $\begin{array}{l}\text { "Effects of storytelling to facilitate EFL } \\
\text { speaking using Web-based multimedia } \\
\text { system" }\end{array}$ & 2016 & 29 & 7.25 \\
\hline 17 & $\begin{array}{l}\text { D. Atwood-Blaine, D. } \\
\text { Huffman }\end{array}$ & $\begin{array}{l}\text { "Mobile Gaming and Student } \\
\text { Interactions in a Science Center: The } \\
\text { Future of Gaming in Science Education" }\end{array}$ & 2017 & 15 & 5 \\
\hline 18 & $\begin{array}{l}\text { F. Garzotto, } \\
\text { M. Gelsomini, } \\
\text { F. Clasadonte, } \\
\text { D. Montesano, } \\
\text { D. Occhiuto }\end{array}$ & $\begin{array}{l}\text { "Wearable immersive storytelling for } \\
\text { disabled children" }\end{array}$ & 2016 & 13 & 3.25 \\
\hline
\end{tabular}

(Continued) 
Table 10. Top 10 highly cited articles (continued)

\begin{tabular}{|c|c|c|c|c|c|}
\hline Ref. & Authors & Title & Year & Cites & $\begin{array}{c}\text { Cites } \\
\text { per Year }\end{array}$ \\
\hline 19 & $\begin{array}{l}\text { D. Harley, J.H. Chu, } \\
\text { J. Kwan, A. Mazalek }\end{array}$ & $\begin{array}{l}\text { "Towards a framework for tangible } \\
\text { narratives" }\end{array}$ & 2016 & 11 & 2.75 \\
\hline 9 & $\begin{array}{l}\text { M. Nakevska, A. van } \\
\text { der Sanden, M. Funk, } \\
\text { J. Hu, M. Rauterberg }\end{array}$ & $\begin{array}{l}\text { "Interactive storytelling in a mixed } \\
\text { reality environment: The effects of } \\
\text { interactivity on user experiences" }\end{array}$ & 2017 & 11 & 3.67 \\
\hline 20 & A. Ramirez, V. Bulitko & $\begin{array}{l}\text { "Automated Planning and Player } \\
\text { Modeling for Interactive Storytelling" }\end{array}$ & 2015 & 10 & 2 \\
\hline 21 & G. Dizon & $\begin{array}{l}\text { "Using Intelligent Personal Assistants } \\
\text { for Second Language Learning: A Case } \\
\text { Study of Alexa" }\end{array}$ & 2017 & 9 & 3 \\
\hline 22 & C. Roth, H. Koenitz & $\begin{array}{l}\text { "Towards creating a body of evidence- } \\
\text { based interactive digital narrative design } \\
\text { knowledge: Approaches and challenges" }\end{array}$ & 2017 & 8 & 2.67 \\
\hline 23 & $\begin{array}{l}\text { T. Wallbaum, } \\
\text { S. Ananthanarayan, } \\
\text { S.S. Borojeni, } \\
\text { W. Heuten, S. Boll }\end{array}$ & $\begin{array}{l}\text { "Towards a tangible storytelling kit for } \\
\text { exploring emotions with children" }\end{array}$ & 2017 & 7 & 2.33 \\
\hline
\end{tabular}

\section{Discussion}

This study assessed the evolution trends in interactive storytelling between the year of 1996 to 2020 through a bibliometric analysis which is viewed through Scopus database. The highest number of publications is observed in 2011. There were 795 studies in the field of interactive storytelling were retrieved from the SCOPUS database and then VOSviewer and Harzing's Perish or Publish software were utilized for further analysis. Conference paper is the topdocument type produced with 592 documents, equivalent to $74.5 \%$. The year 2011 recorded the highest number of publications with 71 documents, equivalent to $8.93 \%$. However, the number of publications decrease in the year 2020 due to the impact of Covid-19 pandemic globally. English language tops the most written language used for publications, equivalent to $99.7 \%$.

Computer Science is the major subject depicted on the studies of Interactive Storytelling with a frequency of 711 , equivalent to $53.5 \%$. Due to this, the Lecture Notes in Computer Science Including Subseries Lecture Notes in Artificial Intelligence and Lecture Notes in Bioinformatics topped the active publishing list with 299 documents, equivalent to $45.65 \%$. There were 159 authors that writes about 1059 documents on interactive storytelling being published by multiple authors. The article titled "Timelines Revisited: A Design Space and Considerations for Expressive Storytelling tops the list with 33 citations within the range of 1059 documents out of 159 authors of the written documents. 


\section{Conclusion}

In a nutshell, the total retrieved data of 795 documents will keep on increasing as it was made at the early stage of year 2020 . However, as time pass by, the total number of annual publications declining in the year 2020 due to the issue of pandemic COVID-19 virus. More research is focussed on how to overcome the global pandemic instead of the other issue. The samples size retrieved are limited due to the limitation existed in the area of interactive storytelling. Future research is recommended to explore a larger number of documents for bibliometric analysis that consists of interactive narratives and non-linear storytelling with broader perspectives in the area of edutainment and creative industry in order to improve the generalisability of the study. Future research should also examine the aspects of social transmedia narratives as a tool related to the creative industry sustainable growth perspectives.

\section{$7 \quad$ Acknowledgement}

The financial support for this work was made available by the Geran Penjanaan of Universiti Utara Malaysia with SO Code: 14591.

\section{$8 \quad$ References}

[1] E. S. Lima, B. Feijó, and A. L. Furtado. (2020). "Adaptive storytelling based on personality and preference modeling," Entertainment Computing, vol. 34, p. 100342. https://doi. org/10.1016/j.entcom.2020.100342

[2] Y. Lee and J. Lee. (2020). "Interactive Game-Content-based Storytelling for the Environment," Sustainability, vol. 12, no. 19, p. 8229. https://doi.org/10.3390/su12198229

[3] E. F. Melcer et al. (2020). Getting Academical: A Choice-Based Interactive Storytelling Game for Teaching Responsible Conduct of Research, pp. 1-12. https://doi. org/10.1145/3402942.3403005

[4] M. C. Abdullah, N. M. Bakhir, and M. S. Sunar. (2014). Innovation in Wayang Kulit Storytelling using Digital Interactive Method. International Journal of Interactive Digital Media, vol. 2 , no. 2, pp. $2-5$.

[5] B. Li and M. Riedl. (2015). Scheherazade: Crowd-powered interactive narrative generation.

[6] S. Rizvic, D. Boskovic, V. Okanovic, S. Sljivo, and M. Zukic. (2020). Interactive digital storytelling: bringing cultural heritage in a classroom. arXiv [cs.HC]. https://doi. org/10.1007/978-3-030-37191-3 18

[7] J. Ducasse, M. Kljun, and K. Čopič Pucihar. (2020). Interactive web documentaries: A case study of audience reception and user engagement on iOtok. Int. J. Hum. Comput. Interact., vol. 36, no. 16, pp. 1558-1584. https://doi.org/10.1080/10447318.2020.1757255

[8] M. Thöny, R. Schnürer, R. Sieber, L. Hurni, and R. Pajarola. (2018). Storytelling in interactive 3D geographic visualization systems. ISPRS Int. J. Geoinf., 7(3), p. 123. https://doi. org/10.3390/ijgi7030123

[9] M. Nakevska, A. Sanden, M. Funk, J. Hu, and M. Rauterberg. (2017). Interactive storytelling in a mixed reality environment: the effects of interactivity on user experiences. Entertainment Computing, vol. 21, pp. 97-104. https://doi.org/10.1016/j.entcom.2017.01.001 
[10] H. Liang, J. Chang, I. K. Kazmi, J. J. Zhang, and P. Jiao. (2017). Hand gesture-based interactive puppetry system to assist storytelling for children. Vis. Comput., 33(4), pp. 517-531. https://doi.org/10.1007/s00371-016-1272-6

[11] J. L. R. Tamayo, M. B. Hernández, and H. G. Gómez. (2018). Digital Data Visualization with Interactive and Virtual Reality Tools. Review of Current State of the Art and Proposal of a Model. Revista ICONO14 Revista científica de Comunicación y Tecnologías emergentes, 16(2), pp. 40-65. https://doi.org/10.7195/ri14.v16i2.1174

[12] M. Castriotta, M. Loi, E. Marku, and L. Naitana. (2019). "What's in a name? Exploring the conceptual structure of emerging organizations," Scientometrics, 118(2), pp. 407-437. https://doi.org/10.1007/s11192-018-2977-2

[13] D. Tunger and M. Eulerich. (2018). "Bibliometric analysis of corporate governance research in German-speaking countries: applying bibliometrics to business research using a custom-made database," Scientometrics, 117(3), pp. 2041-2059. https://doi.org/10.1007/ s11192-018-2919-Z

[14] C. Li, K. Wu, and J. Wu. (2018). Correction to: A bibliometric analysis of research on haze during 2000-2016. Environ. Sci. Pollut. Res. Int., vol. 25, no. 15, p. 15268. https://doi. org/10.1007/s11356-017-0741-4

[15] M. Brehmer, B. Lee, B. Bach, N. H. Riche, and T. Munzner. (2017). Timelines revisited: A design space and considerations for expressive storytelling. IEEE Trans. Vis. Comput. Graph., 23(9), pp. 2151-2164. https://doi.org/10.1109/TVCG.2016.2614803

[16] W.-Y. Hwang, R. Shadiev, J.-L. Hsu, Y.-M. Huang, G.-L. Hsu, and Y.-C. Lin. (2016). "Effects of storytelling to facilitate EFL speaking using Web-based multimedia system," Comput. Assist. Lang. Learn., 29(2), pp. 215-241. https://doi.org/10.1080/09588221.2014. $\underline{927367}$

[17] D. Atwood-Blaine and D. Huffman. (2017). Mobile gaming and student interactions in a science center: The future of gaming in science education. Int. J. Sci. Math. Educ., 15(S1), pp. 45-65. https://doi.org/10.1007/s10763-017-9801-y

[18] F. Garzotto, M. Gelsomini, F. Clasadonte, D. Montesano, and D. Occhiuto. Wearable immersive storytelling for disabled children. In Proceedings of the International Working Conference on Advanced Visual Interfaces.

[19] D. Harley, J. H. Chu, J. Kwan, and A. Mazalek. (2016). Towards a Framework for Tangible Narratives. In Proceedings of the TEI '16: Tenth International Conference on Tangible, Embedded, and Embodied Interaction. https://doi.org/10.1145/2839462.2839471

[20] A. Ramirez and V. Bulitko. (2015). Automated planning and player modeling for interactive storytelling. IEEE Trans. Comput. Intell. AI Games, vol. 7, no. 4, pp. 375-386. https://doi. org/10.1109/TCIAIG.2014.2346690

[21] G. Dizon. (2017). Using intelligent personal assistants for second language learning: A case study of Alexa. TESOL j., 8(4), pp. 811-830. https://doi.org/10.1002/tesj.353

[22] C. Roth and H. Koenitz. (2017). Towards creating a body of evidence-based interactive digital narrative design knowledge: Approaches and challenges. In Proceedings of the 2nd International Workshop on Multimedia Alternate Realities. https://doi. org/10.1145/3132361.3133942

[23] T. Wallbaum, S. Ananthanarayan, S. S. Borojeni, W. Heuten, and S. Boll. (2017). Towards a tangible storytelling kit for exploring emotions with children. In Proceedings of the on Thematic Workshops of ACM Multimedia 2017-Thematic Workshops '17. https://doi. org/10.1145/3126686.3126702 


\section{Authors}

Assoc. Prof. Dr. Norbayah Mohd Suki is an Associate Professor at School of Creative Industry Management \& Performing Arts, Universiti Utara Malaysia, Kedah, Malaysia. Her research interests include Creative Multimedia, Mobile Learning, Animation, HCI, User Experience and Behaviour, etc. She can be reached at bayasuki@, yahoo.com.

Professor Dr. Norazah Mohd Suki is a Professor of Marketing \& E-Commerce at Othman Yeop Graduate School of Business (OYAGSB), Universiti Utara Malaysia. Her research interests include Marketing and E-Commerce. She can be contacted at: azahsuki@yahoo.com.

Rosliza Ahmad is an Asisstant Lecturer at Faculty of Art and Design, Universiti Selangor. Her research interests include Visual Arts, Advertising, Multimedia Technology and Education. She can be reached at liezahmed@unisel.edu.my.

Article submitted 2021-05-04. Resubmitted 2021-06-15. Final acceptance 2021-06-15. Final version published as submitted by the authors. 